This is an Accepted Manuscript of an article published by Taylor \& Francis in Journal of Political Power on 2018,

available online: http://www.tandfonline.com/

https://www.tandfonline.com/doi/full/10.1080/2158379X.2018.1523318 


\section{THROUGH THE LOOKING GLASS: LEADER PERSONHOOD AND THE INTERSUBJECTIVE CONSTRUCTION OF INSTITUTIONS ${ }^{1}$}

\section{Miguel Pina e Cunhaa, ${ }^{\mathrm{a},}$, María José Cardona ${ }^{\mathrm{b}}$, Stewart Clegg ${ }^{\mathrm{c}}$, Jorge F. S. Gomes ${ }^{\mathrm{d}}$, Manuela Matallana $^{\mathrm{b}}$, Arménio Rego ${ }^{\mathrm{e}, \mathrm{f}}$, Iván D. Sánchez ${ }^{\mathrm{g}}$}

${ }^{a}$ Fundação Amélia de Mello Professor of Leadership. Nova School of Business and Economics, Universidade Nova de Lisboa

${ }^{\mathrm{b}}$ School of Management, Universidad de Los Andes,

${ }^{c}$ University of Technology Sydney \& Nova School of Business and Economics, Universidade Nova de Lisboa

${ }^{\mathrm{d}}$ Instituto Superior Economia e Gestão (ISEG), Universidade de Lisboa

${ }^{\text {e }}$ Católica Porto Business School, Universidade Católica Portuguesa

f Instituto Universitário de Lisboa (ISCTE-IUL), Business Research Unit

${ }^{\mathrm{g}}$ School of Business and Economic Studies, Universidad ICESI

\footnotetext{
${ }^{1}$ When the article began life as a composition two of the authors were in residence in two different universities in Colombia: Miguel Cunha thanks the hospitality of the Facultad de Administracion of the Universidad de Los Andes; Jorge Gomes thanks the Facultad de Ciencias Administrativas y Económicas of Universidad ICESI. We are grateful to Filipa Rodrigues for her assistance and to the participants in our session at the BALAS and LAEMOS 2016 conferences for their feedback and suggestions. This work was funded by National Funds through FCT - Fundação para a Ciência e Tecnologia under the project Ref. UID/ECO/00124/2013 and by POR Lisboa under the project LISBOA-01-0145-FEDER-007722. We are grateful to the editor and the reviewers for their important feedback.
}

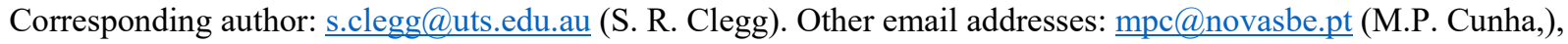
mj.cardona10@uniandes.edu.co (M.J. Cardona), jorgegomes@iseg.ulisboa.pt (J.F.S. Gomes), m.matallana10@uniandes.edu.co (M. Matallana), armenio.rego@ua.pt (A. Rego), idsanchez1@icesi.edu.co (I.D. Sánchez) 


\begin{abstract}
Institutions have been mainly understood in a dualistic way: as abstract, macro cultural logics or as inhabited socio-cultural sites. This form of dualism divided people into cognitive cultural dopes or persons with a heart. Scholars are now trying to overcome dualistic modes of thinking about people in institutions, through the consideration of persons as whole human beings, embodied, embrained and emotional as well as, occasionally, rational actors. In this new theoretical approach it is crucial to understand how institutions frame individual action and how individuals shape institutions. We study this duality by considering the lived experience of an institution as an interactional phenomenon. We do so with a case study of Colombia's presidential transition period from Uribe to Santos in the decade of the 2010s. We consider that the notion of personhood provides a robust explanation of how people engage with institutions and in so doing peer through the institutional looking glass, exploring how leaders shape the institution that shape the rest of people, by framing accounts in terms of emotions.
\end{abstract}

Keywords: Institutions, emotions in institutions, Colombia, personhood, institutional work. 


\section{THROUGH THE LOOKING GLASS:}

\section{LEADER PERSONHOOD AND THE INTERSUBJECTIVE CONSTRUCTION OF INSTITUTIONS}

\section{Introduction}

Institutions have been explained as abstract, macro cultural logics but also as inhabited socio-cultural sites displaying an emotional component, a 'heart' (Voronov, 2014) or as Selznick (1949) put it a 'soul'. In the past, the poles of this tension have often been presented dualistically but more recently scholars have tried to overcome dualistic modes of thinking, emphasizing the interplay of the macro and the micro. In this theoretical approach, it is crucial to understand how institutions frame individual action and how individuals shape institutions. We study this duality by considering the lived experience of institutions not as remote superstructural logics but as something that is daily (re)constructed by embodied human beings, relating with institutions and each other through interaction (Hallett and Ventresca, 2006). We study how institutions shape and are shaped by personhood rather than cognitive 'actorhood' by taking people to be embodied, emotional, socially embedded (Creed et al., 2014) and studying how integral people - people that approach institutions with their full life experience - influence institutions (Creed et al., 2014). We ask: how do leaders mould significant political institutions with their full selves in ways that end up shaping the selves of the many inscribed within their national frame?

We join the stream of research from institutional theory that vigorously defends the notion that 'emotions are central to human experience' and align with those scholars who 'have increasingly recognized their role in institutions' (Voronov and Weber, 2016: 1). We add that human beings express their emotions as part of their context but also as a signification of their full personal history and its biographical narratives. Research on the emotions of institutions is normally characterized by 
the attempt to articulate micro and macro processes, presenting institutions as powerful forces for conformity and compliance (DiMaggio and Powell, 1983) but also as processes influenced by the emotions contained in institutional work emerging from human action and reaction. Emotions have been cast as animators of institutional processes (Voronov and Vince, 2012) and it is through emotional work that people can serve as "carriers" of institutional processes (Hallett and Ventresca, 2006: 215). The role of emotion, as a "relatively intense feeling state which interrupts cognitive processes and/or behaviors" (George, 1995, p. 150) in the leader's construction of institutions has a venerable tradition, from Weber's (1947) work on charisma onwards, and has received continued attention from organization theorists interested in the complex relationship between leaders, namely those who are charismatic, as well as with followers and the unfolding of institutions via their expressed integral selves. Bringing charisma back in is an important endeavour for institutional theory that "lacks feeling, the passions and fears that produce, sustain and disrupt institutional practice" (Friedland, 2018, p. 515).

Emotions are a response to situations but are always filtered through a biographical lens: the way one expresses them is as much the product of situation and biology as it is of social learning and cultural milieu. Therefore, to understand the functioning of institutions one needs to consider the emotions deployed by persons within the context of their full biographical accounts. We adopt a relational ontology of institutions (Cooper, 2005; Voronov, 2014), by seeing institutions, as rooted in relationships as any other human endeavor (Shefer, Carmeli \& Cohen-Meitar, 2017). In such a view, institutions shape agents but also can be shaped by them, especially when they are central and influential, as happens with top-level leaders. Research to date, however, is insufficient to explain some important facets of biography and institution, such as the co-evolving nature of leaders and institutions. The topic has been addressed, among others, by sociologists of emotions but more needs to be known about the relational process through which leaders, especially those perceived as charismatic, channel emotions through institutional power circuits (Clegg, 1989) to reach their 
political aims, in the process shaping institutions and contributing to explain why and how states deploy emotions via their individual leaders (Sasley, 2011). Heaney $(2013,356)$ suggests that power and emotions need to be viewed simultaneously through a 'bifocal lens' in order to avoid theoretical myopia. It is this that we aim to achieve in what follows, as our work contributes to the literature on the conceptual twins of emotions and power (Heaney, 2011), showing how dyadic relationships may reverberate institutionally.

We consider that political leadership succession offers a privileged period of transition to explore the role of emotions in institutional settings because it offers an extreme case of a potentially highly emotional process: first, political leaders are actors deeply vested in the institutions they have constructed, changed, lived in and challenged; second, they have less pressure to conceal their emotions than less powerful actors (Pfeffer, 2010). While doubtless characteristic of leadership generally this is especially valid for political leaders as their succession is more public than is often the case in other settings. Emotions are a relational phenomenon: 'inherently social, dynamic and contextualized', as Voronov (2014: 188) argues. Emotions have been theorized as the raw materials out of which institutions are made (Voronov, 2014). They are highly scripted (Hochschild, 1983) and while institutional representatives tend to follow the script charismatic leaders sometimes prefer to use "feeling rules" in idiosyncratic ways to fulfil their goals. In this paper we peer conceptually through the looking glass: studies have focused on how institutions shape the way we feel about emotions (Jarvis, 2017) but more needs to be known about how the emotions of the powerful shape the institutions that, in turn, shape the way people feel about their feelings. We explore how leaders' inter-subjectivities contribute to shape institutions and how the process is informed by personhood and relationality. Following this lead, we analyse how actors shape institutions via their full personal experience. We study a case in which the above dimensions feature significantly: that of the political relationship between the former Colombian President Álvaro Uribe and President Juan Manuel Santos, which we shall elaborate below. 


\section{Leadership, succession and institutional inter-subjectivity}

The relationships between leaders and their predecessors/successors offer excellent research opportunities. First, because previous leaders still influence the functioning of the organization, as their past institutional work flows through and is embedded in the existing institutions that are being remade (Lanzara, 1998). Legacies can be celebrated or trashed in public, affirmed or resisted in private, with public and private actions not necessarily being in correspondence. Second, when political leadership changes, comparisons are inevitable. New leaders construct their leadership identities, their "leadership brand", in the shadow of the identity of the former leader, especially where the shadow cast is large. Third, incoming political leaders have to gain legitimacy in the role that they now occupy. Formal exercise of influence over the various levers and mechanisms available to them is just one aspect of being in power but ascent to a formal position is only a moment in the process of constructing or failing to construct legitimacy (Watkins, 2003). Finally, the way in which leadership transition is managed is consequential; it can be smooth, but it can also build up rivalries between potential heirs and between heirs and sponsors (Sonnenfeld, 1995).

A new leader does not inscribe leadership on a politically blank slate. Over time, organizational members develop embedded, frequently implicit, lay theories of what leadership should be (Detert and Edmondson, 2011; Schyns and Meindl, 2005). Situated meanings crystallize, with specific vocabularies of motive attributed to leaders (Mills, 1940). Leadership processes can be represented as inscribed in institutional palimpsests resulting from processes of inter-subjective construction, The metaphor of the palimpsest refers to the fact that later institutional layers are cumulative: new institutional layers do not efface previous layers (Cunha et al., 2015) but are deeply sedimented in the stratified practices and memories of institutions (Clegg 1981). The palimpsest is an apt metaphor as every layer of meaning is written over pre-existing layers and each emotional act is produced over 
pre-existing emotional residues. In our case, the fact that an incoming leader intended to write the future over a blank page did not mean that the past could be effaced in its deeper layers.

A process for explaining personhood in institutions is thus associated with collective memory. The topic of memory has received theoretical attention (Moorman and Miner, 1998) but mostly from a cognitive perspective. Organizational memory should not be confused with organizational history. As Judt and Snyder (2012: 277) suggest, 'whereas history of necessity takes the form of a record, endlessly rewritten and re-tested against old and new evidence, memory is keyed to public, nonscholarly purposes'. As such, organizational memory is keyed more to an emotional than an academic register (Páez et al., 2013; Vuori and Huy, 2016). Memories of previous leaders may produce organizational nostalgia (Gabriel, 1993; Orr, 2014) where an image of the foregone leader is romanticized or mythologized (Keyt, 2015; see, for example, how several US presidents, either democratic or republican, romanticize the Lincoln presidency; Koehn, 2016). Nostalgia, as a condition, encourages a sense of 'historical decline and loss', a 'sense of absence' of something that was positive in memory, if not in fact, perpetuating representations of influential past leaders and their rule that are not necessarily realistic (Elliott and Turner, 2012).

Becoming positively memorialized is a process leaders often seek to initiate whilst in office. To the extent that leaders successfully inscribe a positive memory, it can be problematic for incoming successors. Given comparisons, competition with a memory often entails excessive expectations that, as well as other biases (e.g. contrast effect), may hinder the newcomer in affirming their identity and styling it accordingly. Over time, memorialized leaders acquire some characteristics and lose others in a process that often sees charismatic qualities attributed to them (Spector, 2015). Charismatic leaders interrupt the normalcy of political processes through their capacity to exacerbate emotions and to channel attention to new institutional potentials aligned with their personal interests and worldviews (Hummel, 1975). 
An inhabited view of institutions (Hallett and Ventresca, 2006) represents institutional actorhood (Voronov and Weber, 2016) as involving an element of personhood. In this perspective, leaders bring their full selves, including their personal biographical narratives and their emotional experiences, to the shaping of institutions. Leaders with exceptional qualities, i.e. those called charismatic, bring their exceptional biographies to define the shape of institutions and therefore the legitimate ways of thinking and feeling in specific institutional contexts. In spite of the insufficiencies of charismatic views of leadership (Van Knippenberg \& Sitkin, 2013), the power of exceptional leaders in shaping institutions is relevant and the process of leader competition for shaping institutional characteristics needs to be further explored.

Not all leaders are charismatic; indeed, the lack of charisma is more the rule than the exception. When a leader departs having failed to memorialize their time in office positively, it leaves a legacy of disappointments that, dialectically, may be generative of positive sources of hope and revitalization for successors (Luthans et al., 2006). In sum, the succession process is always more than mere replacement; it is a complex drama of formal and private acts that involve not only rational and logical decisions but also biographical and power-related interactions, especially for the dyad occupying centre stage.

\section{Dyads and the dynamics of personhood}

Dyads constitute an important level of organizational analysis, as people routinely engage in personto-person forms of interaction (Tse and Ashkanasy, 2015: 1176). As Simmel (1950) analysed, a dyad is inherently unstable because the actions of either party can terminate the relation. In the case of leader/successor dyads there are several features worth noting. First, succession potentially constitutes an emotionally taxing experience for both the outgoing leader as well as for the incoming one. In some cases, the transition unfolds smoothly and collaboratively but in other cases transitions are marked by tension, conflict and jockeying for position (Mulcahy, 2010). Some leaders desire to 
project influence even after they have formally departed. Second, as the new leader starts to differentiate their identity from that of the predecessor, doing so may be perceived as an attack on the leader or their legacy, creating friction and psychological conflict (Kets de Vries, 1995; Keyt, 2015). Finally, new leaders do not inscribe their heritage at will upon an institutional blank page; leadership is best viewed as written over "institutional palimpsests" with previous inscriptions influencing the reception of further inscriptions. In this sense, leader actions either reinforce or destabilize existing institutional frameworks, including the reactions of former leaders.

Transitions initiate interactions that expose both new and old leader vulnerabilities. If the leader follows the predecessor's vision, they may be accused of being a passive follower, therefore lacking 'command' capacities and losing credibility before followers and other stakeholders. If they decide to change, they may also be criticized on the grounds that strategic instability is negative and that the change is a result of insecurity, narcissism or hubris. Such is the paradox of leader succession: continuity may be equated with lack of leadership while discontinuity may be seen as hubris. To be successful, the successor needs to adopt both differentiating and undifferentiating behavioural strategies (Keyt, 2015). Given these interesting complexities, the role and implications of the emotions of institutions are underexplored but potentially illuminating of the role of personhood in political institutions.

\section{Research method}

To explore the complexity and nuance of the emotions contained and liberated by dyadic exchanges defined by personhood, we focus on the case of the Colombian presidential dyad composed by Álvaro Uribe and Juan Manuel Santos during and after a succession. Uribe presided over Colombia between 2002 and 2010 (inaugurating the presidential re-election modality), and Santos was first elected in 2010 and re-elected in 2014. Santos is in his second presidential mandate (2014-2018) in the period in which this article was written. Hence, the paper's coming into being accompanies an 
open-ended, evolving process, in the spirit of process scholarship, with its focus on evolving phenomena (Langley et al., 2013). Given our goal and its conceptual aims, this does not constitute a limitation. While we provide biographical accounts of both Uribe and Santos (Appendix 1), we are less interested in them as individual 'entities' than in their evolving relationship. In line with a relational ontology of organizing (Uhl-Bien, 2006), we are not so much interested in the effectiveness of leaders and the political implications of their action so much as in the relationship itself, as a process.

We use a qualitative, inductive study as to build theory about a complex political organizational process thus far approached only in a 'tangential manner' (Voronov and Vince, 2012: 60). Our theoretical imagination was grounded in first-hand experience of the research team with Colombia and its political scene, informed by conceptual interest. Because the processes studied did not take place exclusively behind the scenes, as often happens with personal political rivalries in political contexts, the case was transparent. Given that the rivalry was public and notorious, it received intense local coverage as well as international media reporting. The Santos-Uribe dyad represents a revelatory case (Yin, 2009) that renders the salience of the phenomenon of greater interest than more common cases (Eisenhardt et al., 2016).

Emotions have many aspects; they are embodied, embrained and also social. They have been treated sociologically in several distinct ways: as a key component of symbolic interaction; as signs to be interpreted psychoanalytically; as social codes framing interaction rituals; as the object of civilizational processes signalling longue durée shifts in status and stratification, and as learnt behavioural cues designed to elicit customer responses (Turner, 2009, covers many of these; also see Fineman, 2006, for the role of emotions in organization studies). In the case that we discuss we take a perspective on emotions that treats them as a property of public language; that is, we access the display of emotions of leaders through those accounts that they make available to us, accounts that 
we understand as competent actors able to grasp the emotional tenor of accounts (Silverman, 2017). We do not refer to emotions in terms of psychological interiority but only in terms of public displays as constituted discursively. Doing so may be seen as a limit but it is one that we gladly accept: with Blum and McHugh (1971) we regard emotions as socially ascribed rather than interiorly generated; with Mills (1940) we would argue that there is a recognisable situated vocabulary of emotions. We seek to lay groundwork for future research about institutional emotions, given that the topic is conceptually important and in the past has been under-explored.

There are several reasons for an academic focus on this Colombian case. First, there is personal interest, arising from first-hand experience (e.g. Kets de Vries, 2001). Second, the Santos-Uribe dyad affected the peace agreement ending the long unresolved armed conflict between the FARC and the Colombian State, which has blighted the country for fifty years, therefore constituting a major societal change, with relevance for political and organization theory (Eisenhardt et al., 2016). Third, we were able to compose an insider/outsider research team (Bartunek and Louis, 1996), that is, a team composed by Colombians - deeply embedded in the phenomenon - and foreigners with different levels of familiarity with Colombia. Such a team provides an important condition to assure that interpretative biases were mitigated rather than heightened either by the liability of foreignness or by the personal political preferences that can result from close proximity. The procedure allowed us to construct a rich empirical analysis and plausible conceptual interpretation with minimal preference bias, combining distance and intimacy. Fourth, the case provides an exemplary expression of the topic as an extreme case, rendering it particularly adequate for conceptual exploration (Eisenhardt and Graebner, 2007). By 'extreme' we do not mean that the case is politically radical but rather that is presents a general phenomenon of interest in a way that is more transparent and amenable to deep investigation of its roots than tends to happen in less publicized settings. ${ }^{2}$

\footnotetext{
${ }^{2}$ One literal meaning of radical is the root of something; hence, it is a structural metaphor.
} 
We used digital media and published sources, as well as biographical works or autobiographies (Hernández, 2014; Uribe, 2012), and literature specifically dedicated to the relationship between the two presidents (Dávila, 2014). All these elements are public, which means that other researchers can consider the same or other sources to extend or to challenge our interpretation. Beyond this, public information was very widely available, much of it produced by these leaders (e.g. tweets or interviews in national and international media) with respect to selected critical events.

\section{Data sources and analysis process}

We use a combination of biographical method (Cunha, Lewis, Rego \& Smith, 2017; Musson, 1998) and critical incident approach (Flanagan, 1954) to derive event-based stages of the dyadic relationship. The use of institutional biographies has been defended to explore how the lives of specific individuals are entangled with the institutional work they conducted (Lawrence et al., 2011). Likewise, biographies have been recognized as an important method of leadership research, including in highly institutionalized political settings (Shamir et al., 2005; Stein, 2016). In addition to biographies, we consulted other textual sources, such as media and digital information dealing with Colombian politics in general and the Uribe-Santos dyad in particular.

The Colombian researchers selected critical events; the biographies helped us to contextualize events with which the various members of the research team had variable levels of familiarity. The ongoing process of zooming in and out helped stabilize defining moments in the relationship, denoting stages or critical junctures (Dalpiaz et al., 2016), temporally bracketing the case (Langley, 1999). In the spirit of grounded theory, we cycled back and forth between data analysis and interpretation, in order to build reliable interpretations based on the actual data (Murphy et al., 2017). The overall data analysis process is depicted in Figure 1.

Figure 1 about here 
We thus based our analysis in a selection of theoretically sampled (Goulding, 2009) events that constitute critical relational junctures in the post-succession period. Events provide partial and limited accounts of reality in the sense that they are expressions of larger processes; nonetheless, they offer a parsimonious and conceptually revelatory window of observation over a complex personal and political relationship, thus illustrating the processes that triggered their eventual emergence. How agents cope with unexpected and critical events is indicative of their belief structures (Kunisch et al., 2017). Critical events are imbued with an extremity that is conceptually illuminating and provide the building blocks for our process analysis.

To interpret the case we selected a total of 46 media clips created between 2010 and 2016 to reconstitute the process factually, emphasising the 2012-2015 period ${ }^{3}$. In Table 1 we present proof quotes of these media sources. The combination of sources allowed the exploration of the communicative side of the dyadic relationship, that is, the part of the relationship projected to the general public. Political relationships are inherently communicative as they are produced and heard by others in contexts composed by a multitude of interpretative voices (Kornberger et al., 2006), embedded in complex social and institutional networks.

By embedding biographies in events and using events to explain the evolution of the relationship, we considered both individual actors as well as their entanglement in complex institutional processes, therefore situating actors in their institutional context (Hussenot and Missonier, 2016). The use of media accounts permitted the composition of courtroom types of descriptions (i.e., descriptions as factual as possible), and their temporal bracketing (Langley, 1999) in the larger institutional processes. We selected seven events that we considered critical in explaining the Uribe-Santos relationship and its evolution as a political relationship through four different stages after Santos assumed the presidency. The events were discussed and their

\footnotetext{
${ }^{3}$ For space reasons, not included. The full list was submitted to the Editor and can be obtained from the authors.
} 
significance negotiated and agreed within the research team, identifying these events as determinant for the unfolding of the relationship in terms of the emotions that we elicited from the text.

Given that we were analysing the relationship between a new and former leader, we selected events from the time when Santos (as an ex-subordinate) became the new leader. Although interesting from the exploratory point of view, events that occurred when Santos was not yet the leader did not contribute markedly to our research objective. Thus, we identified events with those characteristics coinciding with the period that started with Santos' election. The events identified are the following (see table 1): (1) the election of Santos - a former minister of Uribe's cabinet - as President of Colombia; (2) the public announcement, by President Santos, of peace negotiations with the Fuerzas Armadas Revolucionarias de Colombia-Ejército del Pueblo (FARC-EP), or the Revolutionary Armed Forces of Colombia-People's Army; (3.1 and 3.2) the election of Uribe as Senator of the Centro Democrático party and (4) the re-election of Santos in 2014, against a candidate supported by Uribe's Centro Democrático party; (4.1 to 4.3) the consecutive shooting by FARC-EP of 11 soldiers in Cauca (April 2015) and the deliberate oil spill engineered by the guerrillas (June 2015), regarded by Semana magazine as 'a moment of truth' (Semana, 2015), and the plebiscite to the peace process. Other events could have been selected but these illustrate critical relational junctures, namely a process of initial divergence, initial confrontation and final direct opposition.

\section{Sketches from life: Uribe and Santos}

Álvaro Uribe served as president of Colombia from 2002 to 2010 . He was born in Medellín (Antioquia) in 1952 and identifies as a 'countryman'. His love for horses and horse riding is well known and his family owned important granaries in the department of Antioquia. He received his education mostly in Colombia and started his political life as mayor of Medellín in 1982. He was elected senator from 1984 to 1994, Antioquia governor from 1995 to 1996 . His father was a victim 
of the FARC-EP, which has been suggested as a basis for his hard approach against that insurgent group in psychoanalytic explanations (McCullough et al., 2013) and, perhaps, also his vehement opposition to the peace process.

He attained high levels of political approval as president, in part because of success against the FARC-EP. Being a right-wing hardliner, he benefitted from the help of the U.S. government under the aegis of the so-called Plan Colombia, initiated by his predecessor Andrés Pastrana. At the end of Uribe's term, the state had reassumed control of most of the country and the drug cartels had been severely damaged. Uribe was the first Colombian president to be re-elected, something that entailed a constitutional amendment. He finished his final mandate with a very high approval rating but without the carriage of the further amendments to make a second re-election possible. In $2014-$ already in clear opposition to Santos - he was elected senator.

Juan Manuel Santos was raised amidst a family of politicians. He was born in the capital city of Bogotá, in 1951, in a powerful elite family that held the majority stake in the influential El Tiempo newspaper until 2007. Santos studied in the United Kingdom and in the U.S. and served as minister of foreign trade (1991-1993), minister of finance (2000-2002), and minister of defence (2006-2009), before being elected president in 2010. As minister of defence, he served in Uribe's governments and gained public notoriety with Operation Jaque, which resulted in the liberation of 15 hostages from the FARC-EP, including the former presidential candidate, Ingrid Betancourt. He gained the reputation of being a hawk and his hard stance against the FARC-EP contributed to his political stature $^{4}$. In office, he adopted a 'smart power' approach (Nye, 2008), combining military action with openness to negotiated solution. Uribe eventually became Santos' main political opponent. As president, he played a fundamental role in the projection of the power of state institutions and in

\footnotetext{
${ }^{4}$ The metaphor of the hawk is used in politics as in opposition to doves. Hawks or hardliners are the ones who defend tough, hard power approaches to political issues.
} 
helping the state regain control of its territory. In 2016, Santos was awarded the Nobel Peace Prize for the peace process advanced with the FARC-EP.

Given common political histories and contrasting regional backgrounds, until Santos assumed the presidency, their relationship could be described as institutional. From then on, it evolved: Santos was now president, while Uribe was a former president and still very influential patrician who clearly hankered to retain leadership as indicated by the thwarted constitutional amendment that he sponsored. The case is clearly highly suitable for the purpose of exploring personhood in institutional settings.

\section{Process findings}

Tse and Ashkanasy (2015) argue that dyadic interactions, being dynamically unstable in the ways that Simmel (1950) theorized, will change over time. The Uribe-Santos relationship fits this pattern. We organize our findings narratively, through a sequence of four stages organized around seven critical events, representing different phases in the relationship. Throughout the process there were qualitative relational changes. Their unfolding illustrates the changing nature of the relationship, as well as the importance of the institutional work of positioning personhood for performative purposes in terms of the definitions of relations in institutional settings.

Stage 1: From alignment to misalignment (critical incident: Santos' election and 'admiration' for Hugo Chávez)

The first critical event initially expressed relational alignment. Upon his election Santos paid homage to Uribe as Colombia's best past president. He proclaimed his intention to protect the 'immense' legacy of Uribe, his achievements and his proposals. They shared the same political platform: Partido de la U. Being a former cabinet member of Uribe, Santos and Uribe could, in principle, be 
represented as political allies as well as bearers of compatible ideological positions. The illustrative quotes (see table 1) suggest cordiality at the political and personal levels.

The good auspices were rapidly punctured, however, when Santos invited the then Venezuelan president, Hugo Chávez, to attend his investiture ceremony. Chávez and Uribe had developed a very tense political relationship, such that Santos' invitation was not well received by Uribe. Santos developed a cordial relationship with Chávez, even calling him his 'new best friend', which was received by the Uribists ${ }^{5}$ as treason (Hernández, 2014). The political honeymoon was brief.

\section{Insert Table 1 about here}

\section{Stage 2: From light to deep divergence (critical incident: the peace process)}

Santos was accused of threatening Uribe's policy of 'democratic security' by initiating a peace process with the FARC-EP guerrillas. From the outset, doing so signalled a marked departure from a fundamental pillar of Uribe's past policy rule. As soon as Santos' new diplomatic approach regarding a peace process with the FARC-EP became known, the political divergence became evident. The peace process deviated from Uribe's policies and represented a political and personal breach of trust between the two dignitaries. Uribe, referring to Santos, stated: 'He is handing the country to terrorists' (see table 1). Santos, in turn, asked the opposition to stop sabotaging the peace process. Santos claimed that he and Uribe envisioned the same ends via different means, a statement that appeased neither Uribe nor the Uribists.

The peace process with the FARC-EP constituted a radical departure from Uribe's policies. Uribe had in the past adopted a hard line of extreme force whereas Santos reversed this, favouring instead a softer approach (Nye, 2008). Uribe's strategy of 'revenge' was replaced by Santos' approach of reconciliation (McCullough et al., 2013). The peace negotiations started secretly in

\footnotetext{
${ }^{2}$ Politicians and citizens following or identifying with Uribe's ideas or with his political leadership are termed Uribists.
} 
Havana and when publicly announced marked a clear departure from previous policy. The initial alignment between the two leaders gave way to explicit public disagreement and to progressive personal distancing.

\section{Stage 3: Rupture (Critical incident: Santos’ re-election; Uribe elected senator)}

Once the peace process was set in motion, the political rupture between Uribe and Santos became public and notorious. The 2014 presidential election formalized the divide. Santos' main competitor was Óscar Iván Zuluaga, supported by the Centro Democrático, a new political party co-founded by Uribe, together with an important group of politicians, after resigning from the Partido de la $U$ one year previously. Zuluaga presented himself as the guardian of the values of Uribe, positioning Santos - who aspired to be re-elected - in the opposite camp. The political rupture was formalized electorally. Santos was competing against Uribe. Uribe accused Santos of political abuse: 'Colombia needs a different electoral system that guarantees transparency and prevents abuses such as those committed by Santos' government', he said (in a speech shortly after Santos' re-election, in June 2014 [Radio Macondo, 2014]). Critics, however, noted that Uribe had participated in attempts to legislate additional constitutional amendments. Santos, in contrast, defended that the problematic relationship was due to his personal independence from Uribe: 'He wanted me to be his puppet. Since the first day he has begun to attack me viscerally. He has not stopped attacking me for one day. He says I'm going to die, he calls me traitor, liar, scoundrel. Why? Just because I was not his puppet' (El Espectador, 2014).

Rupture turned to direct, formal and personal opposition in March 2014 before the vote, when Uribe was elected senator. Uribe explained his motivations in his first speech: 'Four years ago, in the midst of a collective expression of confidence and optimism, we elected the current government; we are here to answer and amend the deteriorating security' (El Mundo, 2014). Uribe's explanation was based on political arguments and a sense of personal responsibility for his legacy and its jeopardy. 
Detractors reacted with more personal and emotional arguments: 'I want to congratulate senator Uribe and his group that had a dignified second place. I hope we can leave the hatred, the resentments behind and work for the country' (El Heraldo, 2014). What is central in this event is the fact that for the first time since Uribe left the presidency, he and Santos were formal direct parliamentary opponents. Opposition was no longer mediated and Uribe was not just a retired president but also an active member of the senate.

Stage 4: Enmity (Critical incident: FARC attacks; Plebiscite to the peace process)

Álvaro Uribe used Twitter posts as a political medium, tweeting abundant criticisms of Santos. ${ }^{6}$ For example, he said: 'Santos, please don't deceive us anymore, don't justify the murder of our soldiers with the story of the war you want to end' (Noticias RCN, 2015a). He presented Santos as a deceiver. In addition, Uribe took advantage of all the FARC-EP attacks on the military and national infrastructure to ask Santos to reframe the peace process while at the same time criticizing his government. Political antagonism became personal. Hernández (2014) claimed that Uribe developed a personal hatred towards Santos, which was not publicly reciprocated.

After four years of negotiations, Santos' government reached a peace agreement with the FARCEP. Santos held a plebiscite to enable the people either to endorse or reject the peace agreement. Uribe formally led the campaign against the agreement. Once again, the political rupture was formalized in the polls. Uribe accused Santos of handing over the country to terrorists, guaranteeing impunity for FARC crimes against humanity, turning drug trafficking into a political offence and, he claimed, contributing to make Colombia the next Venezuela - by introducing 'Castro-Chavismo' through the implementation of the peace agreement.

\footnotetext{
${ }^{6}$ Future researchers of other Presidents elsewhere whose extensive use of emotional language and tweets as a medium for its expression may well find a comparative case in some respects in the present study.
} 
The result of the plebiscite was $50.21 \%$ against the peace agreement with $49.79 \%$ support. Because of the narrowness of the margin, Uribe regarded this as a political defeat of Santos. Uribe was endangering an agreement that would stop a conflict of more than 50 years on the basis of a personal grudge, onlookers suggested. According to Uribe's critics, his opposition was highly personal rather than principled: when Uribe was president he had offered greater concessions to paramilitary groups and even to the FARC-EP, to try and negotiate a peace agreement with the government.

Once the result of the plebiscite was known, Santos invited Uribe to send concrete proposals to improve the agreement and he called for 'responsibility, realism and celerity' (Clarin, 2016). Five days after the plebiscite, Santos was awarded the Nobel Peace Prize (El Tiempo, 2016). Once more using twitter, Uribe sarcastically "congratulated" Santos and attacked him once again (Uribe Vélez, 2016). Thus, while Santos tried to establish a "political pact" with his opponents (led by Uribe), Uribe did not stop attacking Santos.

\section{Discussion}

The study of personhood from a relational perspective on an institutional context has been defended as necessary to develop 'an institutionalism that takes interactions seriously' (Hallett and Ventresca, 2006: 217); that is, one that understands institutions as inhabited by actors who bring their true selves including, sometimes, their 'hot emotions' (Rao, 2009). The case suggests that actors may embody institutional scripts in highly idiosyncratic ways that cannot be understood outside the context of the relationship. That helps to explain why abstract and collective entities such as institutions 'have' emotions (Albrow, 1992) and become influenced by emotional contagion, namely via the important emotional work of charismatic leaders. 
Research on leadership and leadership succession has often been based on short time frames (Giambatista et al., 2005) but the case shows that successions can be long-lasting processes that are best apprehended longitudinally. Longitudinal studies capture the necessarily evolving and dynamic unfolding of relationship (Baxter and Montgomery, 1996). The study illuminates those cases in which succession dynamics do not follow preferred paths marked by 'succession planning'. The engagement of a leader and former leader in interdependent rivalries influenced political institutions emotionally, spoiling the choreography of succession dynamics that would have defined a preferred role transition as a highly ritualized and institutionalized drama. Instead, it became one that was discursively signified in terms that were highly personally antagonistic and emotionally charged, signifying the importance attached politically of investing full personhood in institutions, including performing emotionality (Moisender et al., 2016; Voronov and Vince, 2012). In fact, leaders are channels for collective emotional work; they function as emotional frames, carrying emotions through institutions. Their institutional work is fundamentally influenced by their full engagement, as human persons, with institutions. As people change institutions, these institutions also change them: the 'Heraclitian individual' (Langley and Tsoukas, 2010: 3) never steps twice into the same river because leaders are influenced by the institutional work they conduct.

Most research on top-level leaders considers mostly demographic variables (Kunisch et al., 2017), which are certainly important but are too coarse to build a granular theoretical understanding of personal biographies related to strategic decisions. The personal attachments and life stories indicate how in this case our dyad made the process of role handover complex; rather than the leaders acting as 'cultural dopes' shaped by and submitted to institutional scripts, a smooth transition gave way to a complex political game that became institutionally demanding, introducing nuance and conceptual thickness to the role of personhood in institutions. Institutions of political leadership 
should be viewed filtered through the personal-biographical trajectories of their leaders. ${ }^{7}$ Political institutions contain multiple sedimented layers, including emotional layers that can be used to initiate processes of emotional contagion and contamination.

Leaders influence organizations in multiple ways and in some cases their capacities to shape events will still be felt even after they have formally departed from the leading role. As shown in the current case, roles may deviate from dramaturgically normalized scripts. Uribe shifted from being the previous president to becoming an informal opponent before assuming the role of de facto main adversary. The process of role shifting is not well typified in the literature of political leadership. Role interdependence necessarily produces emotional interdependence, with all its respective consequences. We contribute to an understanding of the emotions of institutions by showing the intertwinement of a complex mix of bio-institutional factors.

Emotions surge through leaders' institutionally and performatively dynamic lives as these are represented publically. Rivalries, alliances and enmities change over time, shaped by choices that emerge around critical events made meaningful through different sensemaking processes and performed in various arenas, such as parliament, television, social media, public speeches and more informal rumour and gossip. One of the most pertinent findings of the current case is that, over time, political and emotional factors were intertwined, creating a spiral of political divergence, erosion of confidence and emotional hostility that became amplified into a vicious circle of distrust and enmity that reverberated institutionally. The mutual influence between emotional and rational elements is relevant in understanding the unfolding of emotions in institutional contexts. As Kets de Vries (1995) has highlighted, the practice of leadership is shaped by the leader's deep motives and inner psyche as well as by their respective expression in the context of institutions.

\footnotetext{
${ }^{7}$ The dyads of recent history suggest this most clearly: in Australia, Bob Hawke and Paul Keating, Kevin Rudd and Julia Gillard, as well as Tony Abbott and Malcolm Turnbull; in the UK, Tony Blair and Gordon Brown; in the USA Barack Obama and Donald Trump and Donald Trump and Hilary Clinton. The personal is political in a way that bends and shapes robust institutions.
} 
The present study highlights the extent to which personal aspects embedded in the evolving space between past and present leaders may influence relational expressions of institutions. Emotional intensity is inscribed in the process of dyadic relations between leaders: political relationships evolve emotionally and emotional relationships evolve politically in ways that are publically signalled and represented. Politics and persons are entangled and institutional work can be used as a vehicle for emotion: even though rational approaches to phenomena such as succession might seek, representationally, to disengage both emotions and politics, the smooth surfaces of appearances is thin and brittle, easily punctured and, once pierced, can become the occasion for profound hostility and enmity.

In the case under consideration, the leadership processes created tension and emotional escalation that polarized constituencies, exposing the human face of institutions. In the end, the country was divided between Uribists and Santistas, as expressed in the referendum for the peace process. Institutional processes and emotional work were entangled in the political scene in a more complex way than is predicted by visions of institutions as 'uninhabited places' (Voronov and Yorks, 2015). Institutions are inhabited and thus interpreted (Dalpiaz et al., 2016); they have histories and legacies that are fought over and memorialized. Memorialization commemorates a past that is rapidly receding, threatened by the hastening events of the present, held at bay only by nostalgic yearnings. It is thus hardly surprising that institutions, as our discussion indicates, are emotionally redolent, in particular when they proffer local stages for macro-political actors, which leaders and their successors invariably will be, providing arenas in which putative legacies and the manufacture of nostalgia joust for supremacy with contemporary projects not yet memorialized.

On occasion, legacy and nostalgia can win over present control of the circuits of power by rerouting emotions into nodal points that stand in contradistinction to those presently stabilized. The representation of emotions blends interpretations that publics make of individual psychology, 
mutually created role expectations, biographical histories and socio-political forces. The study, overall, suggests that emotional work in institutional contexts is a process rich in tension that can exacerbate conflict, role ambiguity and ultimately institutional vulnerability through polarization. Not only do institutions frame human emotion; they also become imbued with personhood that moulds institutional work as a vehicle for emotional expression. We thus contribute to understanding the emergence of institutional contradictions, 'ruptures and inconsistencies both among and within the established social arrangements' (Seo and Creed, 2002: 225). Contradictions fuelled by emotional arguments can be used to support change but they can also create polarity and division, especially if they build on dualisms founded on stereotype and prejudice, typifications of good and evil, ultimately rendering institutions more vulnerable.

As predicted by previous work, substantive and personal conflicts are not always kept apart (Jehn, 1997). When these conflicts intersperse, discord becomes personal animosity. Relationships are rich in rational and emotional components and deserve to be studied in their representations as a proper research topic in political leadership and institutional theories. Outgoing leaders often leave a legacy that is not negligible, which therefore permits one to represent institutions as palimpsests, in which emotional layers accumulate and produce deeply textured emotional contexts marked by the biographies of their makers. The personhoods of dominant actors shape the interpretations of their followers.

We invite researchers to explore some possibilities opened by our emergent theorizing. These include but are not limited to topics such as: when and why do departing leaders remain active? How and why do allies become antagonists? What is the effect of public animosity between top leaders over the image and credibility of institutions? How do leaders use the representation of emotions and emotional work as a political tactic? To what extent do media such as twitter predicate emotional work because of the limits to expressing a reasoned argument? The list could continue but this 
sample illustrates the potential of personhood in the definition of a research agenda of the emotions of institutions.

As well as substantive findings contributing to personhood and to institutions as emotional palimpsests, we have made methodological contributions by composing an insider/outsider team and relying on public sources on institutional biographical work (Lawrence et al., 2011). We do not claim to have represented 'the truth' of the matter so much as provide an account that is analytical plausible and empirically well-grounded. Throughout the process, we used the team to build trust in the emergent interpretation, with some members acting as outsiders and interrogating the insiders' guiding of the research process as it unfolded (Murphy et al., 2017). The fact that we used public sources makes the case easily open to scrutiny. Readers can compare our interpretive model with alternative incidents and interpretations. ${ }^{8}$

The comprehension we have reached is grounded and it offers conceptually relevant possibilities for advancing the study of personhood in institutionalized contexts. In the past, important leadership contributions have resulted from the study of U.S. presidents (e.g. House et al., 1991; Winter, 1997); there is no reason why such learning should be confined to presidents in the northern hemisphere. Indeed, in the future, the paper is a pioneering analysis given recent developments in the incumbent of $45^{\text {th }}$ Presidential office-holder in the United States, the analysis of the politics of leadership emotions and institutions, especially in relation to social media. We provide a platform for future research by showing the intricacies of the relation between the integral experiences of actors as persons and the institutional process as well as their change over time, responding to the call to study shifting emotions (Kunisch et al., 2017).

It could be objected that we did not interview the leaders in question; to do so, in our view, would have allowed for rehearsal of well-known scripts already available on the public record that

\footnotetext{
${ }^{8}$ In addition we have presented the study and gathered feedback in major academic conferences in South America.
} 
would have furnished little in the way of additional insight. Reporting the prejudices and biases of the leaders in question is a poor substitute for a research team with differing degrees of familiarity with the case, from different disciplinary inclinations, neutralizing the bias of political allegiances. Nonetheless, the possible juxtaposition of other interpretations may contribute to richer, multilayered forms of understanding the case, as well as the process of emotions in institutions more broadly. Other incidents may provide distinct interpretive lens obtained via the use of other events.

It might be said that, given that it is political relationship, our conclusion could be limited to the political context. In traditional organizational contexts such relationships tend to be played out in private with information more difficult to track, collect and triangulate. The public nature of the case is very much in its favour. Leadership of institutions viewed through the lens of relational theory is a process deeply embedded in context and while every context is unique, the mutual constitution of emotions and institutions is important outside the boundaries of politics. The consideration of leader biographies rather than just general demographic variables in the observation and analysis of leadership dynamics is necessary.

Of course, relational detail is unique: as noted by Uhl-Bien (2006: 666), 'relational perspectives, which are dynamic approaches, are much harder to generalize' than fixed, entity-based perspectives. The study's boundaries are defined by the research question and selection of the case. Using a qualitative and inductive study revealed personhood as process and relation (Giambatista et al. (2005). Despite the limitations it imposes, the method contributed to revealing a complex and textured process with granular detail.

\section{Conclusion}

Leaders are in relation not only with followers but also with other contenders, including their former leaders. The process is often emotionally taxing, with leaders feeling psychologically vulnerable 
(Levinson, 1971). Research on several micro aspects of institutions such as identity, pride, personal worth and role ambiguity, all of which are wrapped in complex biographical narratives, may be significantly enriched by considering succession and the relational, inter-subjective moves it stimulates. The case of the Uribe-Santos relationship suggests that the influence of the former leader does not necessarily fade as soon as a new leader is formally appointed. Analyses of critical biographical incidents involving Uribe and Santos after the latter's election indicate that the intersubjectivity of institutions can be more complicated and nuanced than is predicated by extant theory and that leadership action is an expression of personhood, representationally invoking cognitive, emotional, social and biographical accounts. Political reality, as its architects represent it, is one of complex relationships moulded by continued interdependence, shifting roles, and emotional escalation. The capacity of a leader to retain influence in the absence of formal power and institutional support expresses the role of charisma and its complex relationship with institutional settings.

The observations that we have made seem valid across contexts including businesses, familyowned firms as well as political institutions, from which many other cases could be drawn. We considered an exemplary case to extend the literature on institutionally bounded emotions. We focused on the case of a dyad, a unit of analysis that has received scant research attention. Intense emotionality as political conflict over substantive issues metamorphosed into intense emotional antagonism rooted in deep personal motives and former interactions. Personhood is an exercise involving the leader's whole self as it is constructed over time, in relation to that of significant others. Discounting this relational and emotional quality leaves a blank conceptual space in the field of leadership and institution as personhood. 


\section{References}

Albrow, M. (1992) Sine ira et studio — or do organizations have feelings? Organization Studies 13(3): 313-329.

Bartunek, J. M., and Louis M. R. (1996) Insider-outsider team research. Thousand Oaks: Sage.

Baxter, L. A., and Montgomery B. M. (1996) Relating: Dialogues and dialectics. New York: Guilford.

Blum, A. F., \& McHugh, P. (1971). The social ascription of motives. American Sociological Review, 16(1): 98-109.

Clegg, S. R. (1981) Organization and Control. Administrative Science Quarterly 26, 545-562.

Cooper, R. (2005) Relationality. Organization Studies 26(11): 999-1017.

Douglas Creed, W. E., Hudson, B. A., Okhuysen, G. A., and Smith-Crowe, K. (2014). Swimming in a sea of shame: Incorporating emotion into explanations of institutional reproduction and change. Academy of Management Review, 39(3), 275-301.

Cunha, M.P., Lewis, M.W., Rego, A. \& Smith, W. (2017). Biographical methods in leadership research. In B. Schyns, R. Hall \& P. Neves (Eds.), Handbook of methods on leadership research. Cheltenham, Edward Elgar.

Cunha M. P., Reg,o A., Silva A. F., and Clegg S. R. (2015) An institutional palimpsest? The case of Cambodia's political order, 1970 and beyond. Journal of Political Power 8(3): 431-455.

Dalpiaz, E., Rindova, V., and Ravasi D. (2016) Combining logics to transform organizational agency: Blending industry and art at Alessi. Administrative Science Quarterly 61(3): 347-392. 
Dávila, V. (2014) Enemigos. Santos y Uribe: ¿Por qué se odian? Bogotá: Camm Editores.

Detert, J. R., and Edmondson, A. (2011) Implicit voice theories: Taken-for-granted rules of selfcensorship at work. Academy of Management Journal 54(3): 461-488.

DiMaggio, P. J., and Powell, W. W. (1983) The iron cage revisited: Institutional isomorphism and collective rationality in organizational fields. American Sociological Review 48(2): 147-160.

Eisenhardt, K. M., Graebner, M. E., (2007) Theory building from cases: Opportunities and challenges. Academy of Management Journal 50: 25-32.

Eisenhardt, K. M., Graebner, M. E., and Sonenshein, S. (2016) Grand challenges and inductive methods: Rigor without rigor mortis. Academy of Management Journal 59(4): 1113-1123.

Elliott, A., and Turner B. S. (2012) Debating "the social": Towards a critique of sociological nostalgia. Societies, 2: 14-26.

Fineman, S. 2006. Emotion and organizing. In Clegg S. R.Hardy C.Lawrence T.Nord W. R.(Eds.), The Sage handbook of organization studies (2nd ed.): 675-700. London: Sage.

Flanagan, J. C. (1954) The critical incident technique. Psychological bulletin, 51(4): 327-358.

Friedland, R. (2018). Moving institutional logics forward: Emotion and meaningful material practice. Organization Studies, 39(4), 515-542.

Gabriel, Y. (1993) Emotion in organizations. London: Sage.

George, J. M. (1995). Emotion. In N. Nicholson (Ed.), Blackwell encyclopedic dictionary of organizational behavior (pp.150-151). London: Blackwell. 
Giambatista, R. C., Rowe, W. G. and Riaz, S. (2005) Nothing succeeds like succession: A critical review of leader succession literature since 1994. The Leadership Quarterly 16: 963-991.

Goulding, C. (2009) Grounded theory perspectives in organizational research. In: Buchanan DA (ed) The Sage handbook of organizational research methods. London: Sage Publications, pp. 381394.

Hallett, T., and Ventresca M. (2006) Inhabited institutions: Social interactions and organizational forms in Gouldner's patterns of industrial bureaucracy. Theory and Society 35: 213-236.

Heaney, J. G. (2011) Emotions and power: Reconciling conceptual twins. Journal of Political Power. 4 (2): 259-277.

Heaney, U. G. (2013) Emotions and power: a bifocal prescription to cure theoretical myopia, Journal of Political Power, 6(3): 355-362.

Hernández, J. A. (2014) Santos, el jugador: Política, traición y lealtad. Bogotá: Ediciones B.Hochschild, A. (1983). The managed heart: commercialization of human feeling. Berkeley, CA: University of California Press.

House, R. J., Spangler D., and Woycke J. (1991) Personality and charisma in the U.S. presidency: A psychological theory of leader effectiveness. Administrative Science Quarterly 36: 364-396.

Hummel, R.P. (1975). Psychology of charismatic followers. Psychological Reports, 37, 759-770.

Hussenot, A., and Missonier S. (2016) Encompassing novelty and stability: An events-based approach. Organization Studies 37(4): 523-546.

Hussenot, A., and Missonier S. (2016) Encompassing stability and novelty in organization studies: An events-based approach. Organization Studies 37: 523-546. 
Jarvis, L.C. (2017). Feigned versus felt: Feigning behaviors and the dynamics of institutional logics. Academy of Management Review, 42(2): 306-333.

Jehn, K. A. (1997) A qualitative analysis of conflict types and dimensions in organizational groups. Administrative Science Quarterly 42: 530-557.

Judt, T., and Snyder T. (2012) Thinking the Twentieth century. New York: Penguin.

Kets de Vries, M. F. (1995) Organizational paradoxes (2nd ed.). London: Routledge.

Kets de Vries, M. F. (2001) The anarchist within: Clinical reflections on Russian character and leadership style. Human Relations 54(5): 585-627.

Keyt, A. (2015). Myths \& mortals: Family business leadership and succession planning. Englewood Cliffs: Wiley.

Koehn, N. (2016). Why Lincoln hid his strongest feelings from the public. Harvard Business Review, October 10. Aavailable at: https://hbr.org/2016/10/why-lincoln-hid-his-strongest-feelings-fromthe-public

Kornberger, M., Clegg, S. R. and Carter, C. (2006) Rethinking the polyphonic organization: Managing as discursive practice. Scandinavian Journal of Management 22(1): 3-30.

Kunisch, S., Bartunek, J. M., Mueller, J., \& Huy, Q. N. (2017). Time in strategic change research. Academy of Management Annals, 11(2), 1005-1064.

Langley, A. (1999) Strategies for theorizing from process data. Academy of Management Review 24(4): 691-710. 
Langley, A., and Tsoukas H. (2010) Introducing perspectives on process organization studies. In: Hernes T and Maitlis S (eds) Process, sensemaking, and organizing. Perspectives on process organization studies. Oxford: Oxford University Press, pp. 1-26.

Langley, A., Smallman, C., Tsoukas, H., and Van de Ven, A. H (2013) Process studies of change in organization and management: Unveiling temporality, activity, and flow. Academy of Management Journal 56(1): 1-13.

Lanzara, G. F. (1998) Self-destructive processes in institution building and some modest countervailing mechanisms. European Journal of Political Research 33(1): 1-39.

Levinson, H. (1971) Conflicts that plague family businesses. Harvard Business Review (March): 9098.

Luthans, F,. Youssef, C. M., and Avolio B. J. (2006) Psychological capital: Developing the human competitive edge. New York: Oxford University Press.

McCullough, M. E., Kurzban R., and Tabak B. A. (2013) Cognitive systems for revenge and forgiveness. Behavioral and Brain Sciences 36(1): 1-15.

Mills, C. W. (1940) Situated actions and vocabularies of motive. American Sociological Review 5(6): 904-913.

Moisender, J. K., Hirsto H., and Fahy K. M. (2016) Emotions in institutional work: A discursive perspective. Organization Studies 37(7): 963-990.

Moorman, C., and Miner A. (1998) Organizational improvisation and organizational memory. Academy of Management Review 23(4): 698-723. 
Mulcahy, A (2010) Xerox's former CEO on why succession shouldn't be a horse race. Harvard Business Review 88(10): 47-51.

Murphy C, Klotz A. C. and Kreiner G. E. (2017) Blue skies and black boxes: The promise (and practice) of grounded theory in human resource management. Human Resource Management Review 27: 291-305.

Musson, G. (1998) Life histories. In: Symon G., and Cassell C. (eds.) Qualitative methods and analysis in organizational research: A practical guide. London: Sage Publications, pp. 10-27.

Nye, J .S. (2008) The powers to lead. Oxford: Oxford University Press.

Orr, K. (2014) Local government chief executives' everyday hauntings: Towards a theory of organizational ghosts. Organization Studies 35(7): 1041-1061.

Páez, D., Espinosa A., and Bobowik C. (2013) Emotional climate: How is it shaped, fostered, and changed? In: Hermans D., Rimé B., and Mesquita B. (eds.) Changing emotions. New York: Psychology Press, pp. 113-119.

Pfeffer, J. (2010). Power. New York: Harper.

Rao, H. (2009) Market rebels: How activists make or break innovations. Princeton, NJ: Princeton University Press.

Sasley, B. E. (2011). Theorizing States emotions. International Studies Review. 13 (3): 452-476.

Schyns, B., and Meindl J. R. (2005) An overview of implicit leadership theories and their application in organizational practice. In: Schyns B., and Meindl J. R. (eds) Implicit leadership theories: Essays and explanations. Greenwich, CT: Information Age, pp.15-36. 
Selznick, P. (1949). TVA and the grass roots: a study in the sociology of formal organization. Berkeley, CA: University of California Press.

Seo, M. G., and Creed W. E. D. (2002) Institutional contradictions, praxis and institutional change: A dialectical perspective. Academy of Management Review 27(2): 222-247.

Shamir, B., Dayan-Horesh H., and Adler D. (2005) Leading by biography: Towards a life-story approach to the study of leadership. Leadership 1(1): 13-29.

Shefer, N., Carmeli, A., and Cohen-Meitar, R. (2017). Bringing Carl Rogers back in: Exploring the power of positive regard at work. British Journal of Management, DOI10.1111.14678551.12247

Silverman, D. (2017). Doing qualitative research. London: Sage.

Simmel, G. (1950). The dyad and the triad. The Sociology of Georg Simmel, New York: Simon and Schuster, 59-68.

Sonnenfeld, S. (1995) When the CEO can't let go. Harvard Business Review 73(5): 24-36.

Spector, B. A. (2015) Carlyle, Freud, and the great man theory more fully considered. Leadership 12(2): 250-260.

Stein, M. (2016) 'Fantasy of fusion' as a response to trauma: European leaders and the origins of the Eurozone crisis. Organization Studies 37(7): 919-937.

Tse ,H. H. M., and Ashkanasy N. M. (2015) The dyadic level of conceptualization and analysis: A missing link in multilevel OB research? Journal of Organizational Behavior 36(8): 1176-1180. 
Turner, J. H. (2009) The sociology of emotions; basic theoretical arguments, Emotion Review, 1(4): 340-354.

Uhl-Bien, M. (2006) Relational leadership theory: Exploring the social processes of leadership and organizing. The Leadership Quarterly 17(6): 654-676.

Uribe, A. (2012) No lost causes. London: Celebra.

Uribe ,A. (2014). Biografía. Retrieved June 2015, from $\underline{\text { http://www.alvarouribevelez.com.co/es/biografia }}$

Van Knippenberg, D., \& Sitkin S. B. (2013) A critical assessment of charismatic-transformational leadership research: Back to the drawing board? Academy of Management Annals, 7(1), 1-60.

Voronov, M. (2014) Toward a toolkit for emotionalizing institutional theory. Research on Emotions in Organizations 10: 167-196.

Voronov, M., and Vince R. (2012) Integrating emotions into the analysis of institutional work. Academy of Management Review 37(1): 58-81.

Voronov, M., and Weber K. (2016) The heart of institutions: Emotional competence and institutional actorhood. Academy of Management Review 41(3): 1-23.

Voronov, M., and Yorks L. (2015) "Did you notice that?" Theorizing differences in the capacity to apprehend institutional contradictions. Academy of Management Review 40(4): 563-586.

Vuori, T. O., and Huy Q. N. (2016) Distributed attention and shared emotions in the innovation process: How Nokia lost the smartphone battle. Administrative Science Quarterly 61(1): 9-51. 
Watkins, M. (2003) The first 90 days: Critical success strategies for new leaders at all levels. Boston, MA: Harvard Business Press.

Weber, M. (1947). The theory of social and economic organization. New York: Oxford University Press.

Winter, D. G. (1987) Leader appeal, leader performance, and the motive profiles of leaders and behaviors: A study of American presidents and elections. Journal of Personality and Social Psychology, 52(1): 196-202.

Yin, R. K. (2009) Case Study Research: Design and methods ( $4^{\text {th }}$ ed.). Thousand Oaks: Sage. 


\section{Appendix 1}

\section{Biographical notes of Uribe and Santos}

\section{1. Álvaro Uribe}

\begin{tabular}{|c|c|}
\hline Dates & Facts \\
\hline 1952 & Álvaro Uribe was born in Medellín \\
\hline 1977 & $\begin{array}{l}\text { He finished his doctoral degree in Law and Political Science at Universidad de } \\
\text { Antioquia }\end{array}$ \\
\hline 1980-1982 & Director of Civil Aviation \\
\hline $1982-1983$ & Mayor of Medellín \\
\hline 1984-1986 & Councilman of Medellín \\
\hline 1986-1994 & $\begin{array}{l}\text { Senator of Colombia (Liberal Party). Uribe obtained the award of the "best senator" in } \\
1990,1992 \text { and 1993. Also, he was the senator with the "best legislative initiatives" in } \\
1992\end{array}$ \\
\hline 1993 & $\begin{array}{l}\text { Obtained the certificate of Special Studies in Administration and Management at } \\
\text { Harvard University }\end{array}$ \\
\hline 1995-1997 & Governor of Antioquia \\
\hline 1998 & $\begin{array}{l}\text { The British Council gave him the Simón Bolívar scholarship and he was designated } \\
\text { 'Senior Associate Member' of the Saint Antony's College at Oxford University }\end{array}$ \\
\hline $2002-2006$ & President of Colombia (candidate of the movement Primero Colombia) \\
\hline 2005 & He founded the political party Partido de la $U$ \\
\hline $2006-2010$ & Reelected as President of Colombia (candidate of Partido de la $U$ ) \\
\hline 2013 & $\begin{array}{l}\text { Uribe founded the political party "Centro Democrático" with his ex-minister Óscar } \\
\text { Iván Zuluaga, the senator Juan Carlos Vélez Uribe, the ex-ambassador Carlos Holmes } \\
\text { Trujillo García, his ex-vice-president Francisco Santos Calderón and his ex-vice- } \\
\text { minister of defense Rafael Guarín }\end{array}$ \\
\hline 2013 & $\begin{array}{l}\text { The Inte Group awarded him as the "Best Latin American Political Leader of the } \\
\text { Decade" }\end{array}$ \\
\hline $\begin{array}{l}\text { 2014- } \\
\text { Today }\end{array}$ & Senator of Colombia. He received the 'Best Senator' award in 2014 \\
\hline $\begin{array}{l}\text { 2010- } \\
\text { Today }\end{array}$ & Lecturer and professor \\
\hline
\end{tabular}




\subsection{Juan Manuel Santos}

\begin{tabular}{ll}
\hline Dates & Facts \\
\hline 1951 & Juan Manuel Santos was born in Bogotá \\
\hline $1972-1981$ & $\begin{array}{l}\text { Santos was the Chief Executive of the National Federation of Coffee Growers of } \\
\text { Colombia to the International Coffee Organization in London, UK }\end{array}$ \\
\hline 1973 & $\begin{array}{l}\text { He graduated with a bachelor degree in Economics and Business Administration at } \\
\text { the University of Kansas, USA }\end{array}$ \\
\hline 1975 & Master of Science in Economic Development at London School of Economics, UK \\
\hline 1981 & $\begin{array}{l}\text { Master in Public Administration at Harvard University, USA. He earned the } \\
\text { Fullbright scholarship at The Fletcher School of Law and Diplomacy at Tufts }\end{array}$ \\
\hline $1981-1991$ & University (USA) and also at Fundación Nieman at Harvard University, USA \\
\hline $1991-1993$ & Minister of Foreign Trade \\
\hline $1993-1994$ & Presidential Designate \\
\hline $2005-1997$ & Director of the Liberal Party \\
\hline 2005 & Minister of Finance and Pubic Credit \\
\hline $2006-2009$ & Founded the political party: Partido de la U
\end{tabular}


Figure 1

The overall data analysis process

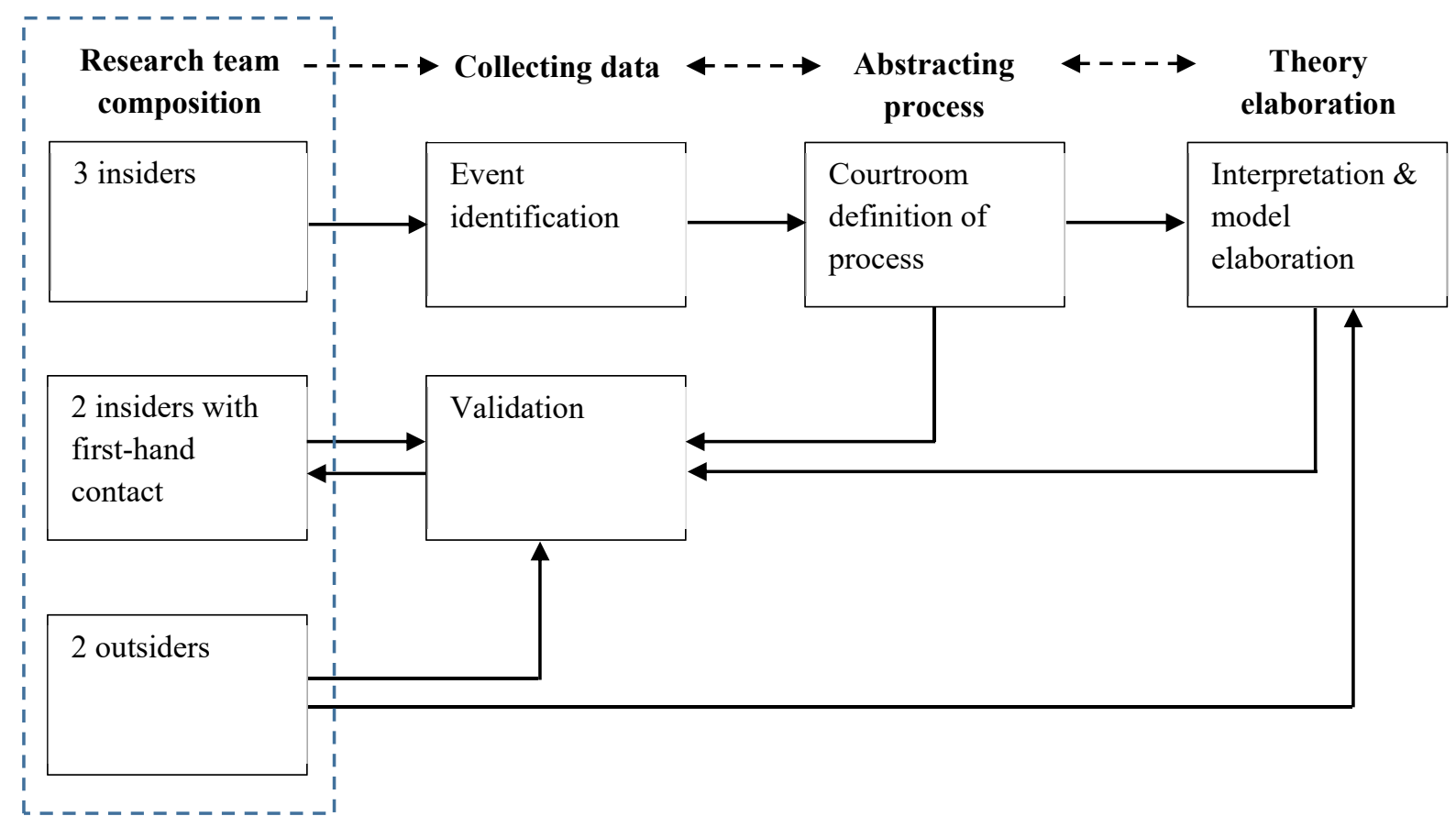


Table 1

Main stages in the process and correspondent critical incidents

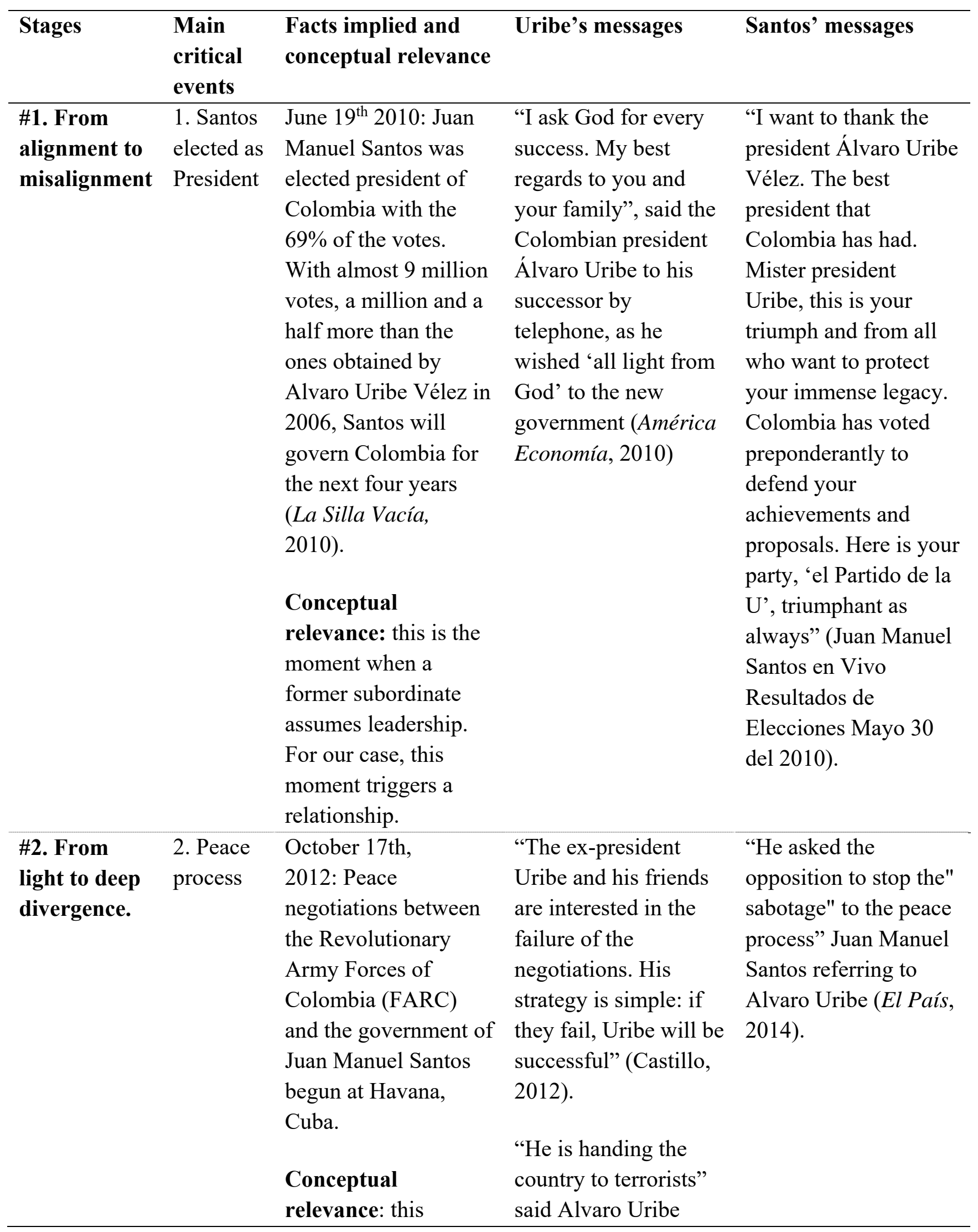




\begin{tabular}{|c|c|c|c|c|}
\hline & & $\begin{array}{l}\text { episode captures the } \\
\text { most central } \\
\text { dimension of Santos' } \\
\text { presidency and a } \\
\text { departure from } \\
\text { Uribe's strategy. }\end{array}$ & $\begin{array}{l}\text { referring to Juan } \\
\text { Manuel Santos' } \\
\text { government (El País, } \\
\text { 2014). }\end{array}$ & \\
\hline \multirow[t]{3}{*}{$\begin{array}{l}\text { \#3. From } \\
\text { contest and } \\
\text { conflict, to } \\
\text { opposition } \\
\text { and hostility }\end{array}$} & \multirow[t]{2}{*}{$\begin{array}{l}3.1 . \\
\text { Santos } \\
\text { reelection }\end{array}$} & $\begin{array}{l}\text { June 15th, 2014: Juan } \\
\text { Manuel Santos was } \\
\text { reelected as the } \\
\text { President of Colombia } \\
\text { with the } 50,93 \% \text { of } \\
\text { votes in the second } \\
\text { round. } \\
\text { Conceptual } \\
\text { relevance: Santos is } \\
\text { re-elected against the } \\
\text { candidate supported } \\
\text { by Uribe. Increased } \\
\text { legitimacy for Santos } \\
\text { to prosecute his own } \\
\text { ideas. }\end{array}$ & $\begin{array}{l}\text { Alvaro Uribe said: } \\
\text { "Colombia needs a } \\
\text { different electoral } \\
\text { system that guarantees } \\
\text { transparency and } \\
\text { prevents abuses such } \\
\text { as those committed by } \\
\text { the Santos' } \\
\text { government" } \\
\text { (Vanguardia, 2014). }\end{array}$ & $\begin{array}{l}\text { "He wanted me to be } \\
\text { his puppet. Since the } \\
\text { first day he has begun } \\
\text { to attack me viscerally. } \\
\text { He has not stopped } \\
\text { attacking me for one } \\
\text { day. He says I 'm } \\
\text { going to die, he tells } \\
\text { me traitor, liar, } \\
\text { scoundrel Why? Just } \\
\text { because I was not his } \\
\text { puppet" said Juan } \\
\text { Manuel Santos } \\
\text { referring to Alvaro } \\
\text { Uribe } \\
\text { (lainformación.com, } \\
\text { 2014) }\end{array}$ \\
\hline & & & & $\begin{array}{l}\text { "Santos said he will } \\
\text { rule 'with the greatest } \\
\text { respect to my political } \\
\text { opponents"'(CNN } \\
\text { español, 2014) }\end{array}$ \\
\hline & $\begin{array}{l}3.2 \text { Uribe } \\
\text { elected as } \\
\text { Senator }\end{array}$ & $\begin{array}{l}\text { March } 9^{\text {th }}, 2015 \text { : The } \\
\text { ex-president Álvaro } \\
\text { Uribe Vélez, from the } \\
\text { "Centro Democrático" } \\
\text { party obtained the } \\
\text { first curul in the } \\
\text { Senate for 2014-2018 } \\
\text { (El Heraldo, 2014). } \\
\text { Conceptual } \\
\text { relevance: Uribe's } \\
\text { opposition becomes } \\
\text { formal and personal, } \\
\text { non-mediated. }\end{array}$ & $\begin{array}{l}\text { "Four years ago, in } \\
\text { the midst of a } \\
\text { collective expression } \\
\text { of confidence and } \\
\text { optimism, we elected } \\
\text { the current } \\
\text { government; We are } \\
\text { here to answer and } \\
\text { amend the } \\
\text { deteriorating security, } \\
\text { [...] the lack of } \\
\text { Government to listen } \\
\text { to the social and } \\
\text { productive sectors" }\end{array}$ & $\begin{array}{l}\text { "I want to congratulate } \\
\text { the senator Uribe and } \\
\text { his group that had a } \\
\text { dignified second } \\
\text { place". I hope we can } \\
\text { leave the hatred, the } \\
\text { resentments behind } \\
\text { and work for the } \\
\text { country" (El Heraldo, } \\
\text { 2014). }\end{array}$ \\
\hline
\end{tabular}




\begin{tabular}{|c|c|c|c|c|}
\hline & & & $\begin{array}{l}\text { said Alvaro Uribe in } \\
\text { his speech after being } \\
\text { elected as Senator } \\
\text { (Uribe, 2014). }\end{array}$ & \\
\hline \multirow[t]{2}{*}{ \#4. Enmity } & $\begin{array}{l}\# 4.1 \\
\text { FARC } \\
\text { attacks } \\
\text { (1) }\end{array}$ & $\begin{array}{l}\text { April } 15^{\text {th }}, 2015: \\
\text { Eleven soldiers died } \\
\text { after being ambushed } \\
\text { by armed men dressed } \\
\text { as civilians in the } \\
\text { village of Buenos } \\
\text { Aires, in the } \\
\text { department of Cauca. } \\
\text { The attack was } \\
\text { attributed to the } \\
\text { FARC's "Miller } \\
\text { Perdomo" mobile } \\
\text { column (Noticias } \\
\text { RCN, 2015b). }\end{array}$ & $\begin{array}{l}\text { Twitter post: "Santos, } \\
\text { please don't deceive } \\
\text { us anymore, don't } \\
\text { justify the murder of } \\
\text { our soldiers with the } \\
\text { story of the 'war you } \\
\text { want to end" (Noticias } \\
\text { RCN, 2015a). } \\
\text { Uribe asked the } \\
\text { National Government } \\
\text { to make a "pause" to } \\
\text { "reorganize the peace } \\
\text { process with the } \\
\text { guerrilla". } \\
\text { "There has to exist a } \\
\text { guarantee of } \\
\text { seriousness and that } \\
\text { the FARC accept, as a } \\
\text { credibility gesture, to } \\
\text { be concentrated in a } \\
\text { place for a unilateral } \\
\text { suspension of criminal } \\
\text { activities" (El } \\
\text { Heraldo, 2015). }\end{array}$ & $\begin{array}{l}\text { Twitter post: "I'm } \\
\text { sorry about the dead of } \\
\text { soldiers in Cauca. This } \\
\text { is exactly the war we } \\
\text { want to end" (Noticias } \\
R C N, 2015 \mathrm{a}) \text {. } \\
\text { "I've given the order } \\
\text { to the lift the bombing } \\
\text { restrictions". } \\
\text { Santos stated he } \\
\text { wouldn't let this vile } \\
\text { actions pressure the } \\
\text { decision about the } \\
\text { bilateral suspension of } \\
\text { fire. "The decision } \\
\text { can't and won't be } \\
\text { made like this, but as a } \\
\text { consequence of a } \\
\text { serious, definitive and } \\
\text { verified agreement for } \\
\text { the end of the conflict" } \\
\text { (El Heraldo, 2015). }\end{array}$ \\
\hline & $\begin{array}{l}\# 4.2 . \\
\text { FARC } \\
\text { attacks } \\
(2)\end{array}$ & $\begin{array}{l}\text { June } 8^{\text {th }}, 2015 \text { : The } \\
\text { guerilla intercepted } 19 \\
\text { tanker trucks near } \\
\text { Puerto Asis in the } \\
\text { department of } \\
\text { Putumayo. They } \\
\text { forced the trucks to } \\
\text { empty } 204.275 \text { barrels } \\
\text { of crude oil on the } \\
\text { road. }\end{array}$ & $\begin{array}{l}\text { "We are suffering the } \\
\text { consequences of five } \\
\text { years of deteriorating } \\
\text { security, and there is } \\
\text { where the economy } \\
\text { and social policy are } \\
\text { going" said Alvaro } \\
\text { Uribe criticizing Juan } \\
\text { Manuel Santos } \\
\text { government (Costa } \\
\text { Noticias, 2015). } \\
\text { "Uribe said that today, } \\
\text { the FARC entertain }\end{array}$ & $\begin{array}{l}\text { Juan Manuel Santos } \\
\text { said: "In Havana we } \\
\text { are negotiating to end } \\
\text { the conflict, we are } \\
\text { there making peace } \\
\text { and I want to take this } \\
\text { opportunity to tell } \\
\text { these gentlemen of the } \\
\text { FARC, that it is not } \\
\text { the way to show } \\
\text { Colombians that you } \\
\text { want peace, through } \\
\text { attacks as the one of } \\
\text { yesterday" (El }\end{array}$ \\
\hline
\end{tabular}




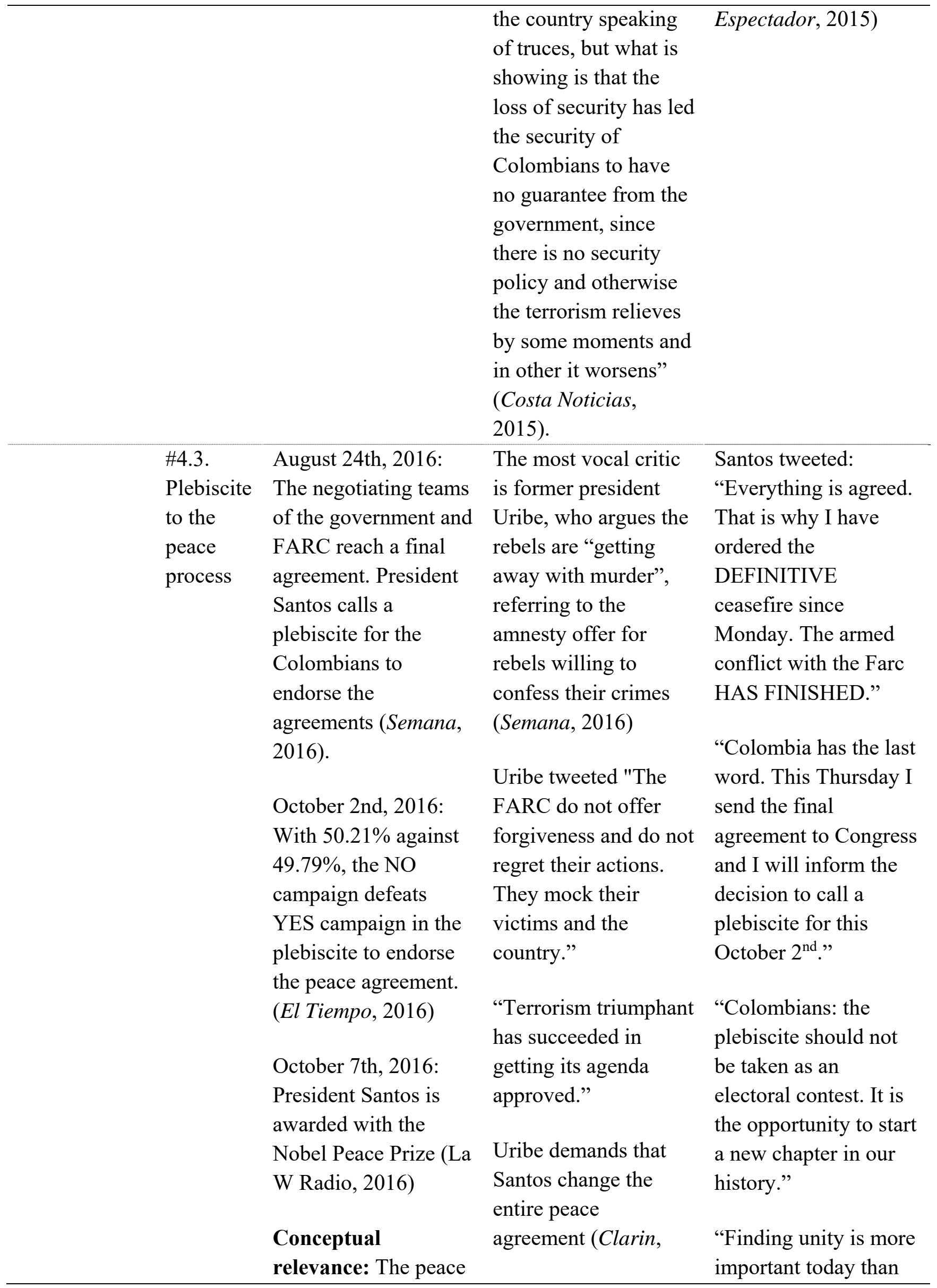


processes constitutes

the most divisive

issue opposing Uribe

and Santos.
2016)

ever. I thank the

support of the parties

to open a national

dialogue for peace."

"I have invited Uribe

to discuss this

Wednesday with a constructive spirit for peace"

Santos claimed

"responsibility, realism and celerity" in the opposition's

Uribe tweeted: "I proposals (Clarin, congratulate the Nobel 2016).

for President Santos, I want it to lead to Santos: "I receive this change harmful agreements for democracy"
Nobel Prize on behalf of millions of victims of the conflict in Colombia." (BBC, 2016) 